\title{
PENTINGNYA PENERAPAN K3 DALAM MEMBRIKAN ASUHAN \\ KEPERAWATAN di LAYANAN KESEHATAN
}

\section{Hanita Grace Sagala}

\section{Email : hanitagrace10@gmail.com}

\begin{abstract}
ABSTRAK
Kesehatan kerja merupakan masalah setiap individu karena bekerja dibutuhkan semua orang sebagai sumber pendapatan untuk memenuhi kebutuhan hidup. Sejak lama diketahui bahwa bekerja dapat menyebabkan gangguan kesehatan atau penyakit. Pelaksanaan Kesehatan dan Keselamatan Kerja (K3) adalah salah satu bentuk upaya untuk menciptakan tempat kerja yang aman sehat, bebas dari pencemaran lingkungan, sehingga dapat mengurangi dan atau bebas dari kecelakaan kerja dan penyakit akibat kerja yang pada akhimya dapat meningkatkan efisiensi dan produktivitas kerja. Kesehatan dan Keselamatan Kerja sangat penting untuk dilaksanakan pada semua bidang pekerjaan.
\end{abstract}

Kata kunci : konsep k3, asuhan keperawatan, layanan kesehatan

\section{LATAR BELAKANG}

Kesehatan kerja merupakan masalah semua orang karena bekerja adalah bagian kehidupan dan orang memerlukan pekerjaan sebagai sumber penghasilan yang diperlukan untuk memenuhi kebutuhan hidup. Namun, sejak lama diketahui bahwa bekerja dapat menimbulkan gangguan kesehatan atau penyakit, dan sebaliknya kesehatan dapat mengganggu pekerjaan.

Keselamatan dan kesehatan kerja difilosofikan sebagai suatu pemikiran dan upaya untuk menjamin keutuhan dan kesempurnaan baik jasmani maupun rohani tenaga kerja pada khususnya dan manusia pada umumnya, hasil karya dan budayanya menuju masyarakat makmur dan sejahtera. Sedangkan pengertian secara keilmuan adalah suatu ilmu pengetahuan dan penerapannya dalam usaha mencegah kemungkinan terjadinya kecelakaan dan penyakit akibat kerja. Kesehatan dan keselamatan Kerja (K3) tidak dapat dipisahkan dengan proses produksi baik jasa maupun industri.

Kesehatan dan Keselamatan Kerja (K3) merupakan upaya untuk menciptakan suasana bekerja yang aman, nyaman dan untuk mencapai tujuan yang produktivitas setinggi-tingginya. Kesehatan dan Keselamatan Kerja sangat penting untuk 
dilaksanakan pada semua bidang pekerjaan seperti proyek pembangunan gedung seperti apartemen dan tanpa terkecuali di bidang kesehatan yaitu di rumah sakit dan lain-lain, karena penerapan K3 itu sendiri dapat mencegah dan mengurangi resiko terjadinya kecelakaan maupun penyakit akibatmelakukan kerja.

Pelaksanaan Kesehatan dan

Keselamatan Kerja (K3) adalah salah satu bentuk upaya untuk menciptakan tempat kerja yang aman sehat, bebas dari pencemaran lingkungan, sehingga dapat mengurangi dan atau bebas dari kecelakaan kerja dan penyakit akibat kerja yang pada akhimya dapat meningkatkan efisiensi dan produktivitas kerja. Kecelakaan kerja tidak saja menimbulkan korban jiwa maupun kerugian materi bagi pekerja dan pengusaha, tetapi juga dapat mengganggu proses produksi secara menyeluruh, merusak lingkungan yang pada akhirnya akan berdampak pada masyarakat luas.Penyakit Akibat Kerja (PAK) dan Kecelakaan kerja (KK) di kalangan petugas kesehatan dan non kesehatan kesehatan di Indonesia belum terekam dengan baik. Jika kita pelajari angka kecelakaan dan penyakit akibat kerja di beberapa negara maju (dari beberapa pengamatan) menunjukan kecenderungan peningkatan prevalensi. Sebagai faktor penyebab, sering terjadi karena kurangnya kesadaran pekerja dan kualitas serta keterampilan pekerja yang kurang memadai. Banyak pekerja yang meremehkan risiko kerja, sehingga tidak menggunakan alat-alat pengaman walaupun sudah tersedia Rumah Sakit (RS) termasuk ke dalam kriteria tempat kerja dengan berbagai ancaman bahaya yang dapat menimbulkan dampak kesehatan, tidak hanya teradap para pelaku langsung yang bekerja di RS, tapi juga terhadap pasien maupun pengunjung RS.

\section{METODE}

Metode dalam penulisan ini dilakukan dengan mengumpulkan data dari buku, jurnal, dan thesis dan e-book, kemudian melakukan analisis secara mendalam terkait topik yang dibahas, serta bersifat subjektif yaitu proses penulisan yang lebih fokus pada landasan teori. Dan melakukan analisis buku dan e-jurnal yang relevan dan berfokus kepada pengaplikasian berfikir kritis dalam mengelola informasi dan komunikasi keperawatan. Adapun ejurnal yang digunakan ini adalah dengan menggunakan google dengan memasukkan kata kunci “ Konsep Dasar K3”. Jurnal yang digunakan adalah jurnal yang diterbitkan 8 tahun terakhir. Adapun referensi akan dicantumkan dalam penulisan ini dengan jelas terdapat pada daftar pustaka pada bagian akhir penulisan. 


\section{HASIL}

Kesehatan dan Keselamatan Kerja (K3) merupakan upaya untuk menciptakan suasana bekerja yang aman, nyaman dan untuk mencapai tujuan yang produktivitas setinggi-tingginya. Kesehatan dan Keselamatan Kerja sangat penting untuk dilaksanakan pada semua bidang pekerjaan seperti proyek pembangunan gedung seperti apartemen dan tanpa terkecuali di bidang kesehatan yaitu di rumah sakit dan lain-lain, karena penerapan K3 itu sendiri dapat mencegah dan mengurangi resiko terjadinya kecelakaan maupun penyakit akibatmelakukan kerja.

Dan tujuan K3 juga merupakan mencegah, megurangi, bahkan menihilkan resiko penyakit dan kecelakaan akibat kerja (KAK) serta meningkatkan derajat kesehatan para pekerja sehingga produktivitas kerja meningkat. Dalam Undang-Undang Republik Indonesia Nomor36 Tahun 2009 Tentang Kesehatan, upaya kesehatan kerja ditunjukkan untuk melindungi pekerja agar hidup sehat dan terbebas dari gangguan kesehatan serta pengaruh buruk yang diakibatkan oleh pekerjaan sehingga sudah seharusnya pihak pengelola RS menerapkan upayaupaya K3 di RS. K3 termasuk sebagai salah satu standar pelayanan yang dinilai di dalam akreditasi RS, disamping standar pelayanan lainnya.

\section{PEMBAHASAN}

Keselamatan dan kesehatan kerja di tempat kerja merupakan salah satu aspek penting yang perlu mendapatkan perhatian serius, karena apabila hal tersebut diabaikan maka kecekaan yang dialami oleh para pekerja akan berakibat pada turunnya kualitas kerja yang di lakukan oleh para pekerja itu sendiri, sehingga segala bentuk kegiatan yang dilakukan akan mengalami gangguan seperti tenaga kerja yang diperlukan menjadi berkurang.

Pengertian Kesehatan dan Keselamatan Kerja secara keilmuan adalah suatu ilmu pengetahuan dan penerapannya dalam usaha mencegah kemungkinan terjadinya kecelakaan dan penyakit akibat kerja. Adapun di Negara kita, Undangundang Dasar 1945 yang mengisyaratkan bahwa setiap warga Negara Republik Indonesia berhak mendapatkan pekerjaan yang layak bagi kemanusian. Dan pekerjaan baru memenuhi kelayakan bagi kemanusiaan apabila keselamatan tenaga kerja dalam menjalankan pekerjaan terjamin (UUD1945 pasal 27).

Kesehatan dan keselamatan kerja adalah suatu pemikiran dan upaya untuk menjamin keutuhan dan kesempurnaan baik jasmaniah maupun rohaniah tenaga kerja pada khususnya, dan manusia pada umumnya, hasil karya dan budaya untuk menuju masyarakat adil dan makmur. Perlindungan tenaga kerja meliputi aspek- 
aspek yang cukup luas yaitu perlindungan keselamatan, kesehatan, pemeliharaan moral tenaga kerja serta perlakuan yang sesuai dengan martabat manusia dan moral agama.

Pengertian kebijakan seperti ini dapat kita gunakan dan relatif memadai untuk keperluan pembicaraan-pembicaraan biasa, namun menjadi kurang memadai untuk pembicaraan-pembicaraan yang bersifat ilmiah dan sistematis menyangkut analisis kebijakan publik. Robert Eyestone (dalam Winarno, 2002:15) mengatakan bahwa secara luas kebijakan publik dapat didefinisikan sebagai hubungan suatu unit pemerintah dengan lingkungannya. Konsep yang ditawarkan Eyestone ini mengandung pengertian yang sangat luas dan kurang pasti karena apa yang dimaksud dengan kebijakan publik dapat mencakup banyak hal. Suatu kebijakan dikatakan sebagai kebijakan publik apabila membawa manfaat yang diperoleh masyarakat yang bukan pengguna langsung dari produk yang dihasilkan, jauh lebih banyak dan lebih besar dari pengguna langsungnya.

Implementasi kebijakan adalah tahap pembuatan kebijakan antara pembentukan kebijakan dan konsekuensi-konsekuensi kebijakan bagi masyarakat yang dipengaruhinya. Jika suatu kebijakan tidak tepat atau tidak dapat mengurangi masalah yang merupakan sasaran kebijakan, maka kebijakan itu mungkin akan mengalami kegagalan sekalipun kebijakan itu di implementasikan dengan sangat baik. Sementara itu, suatu kebijakan yang cemerlang mungkin juga akan mengalami kegagalan jika kebijakan tersebut kurang diimplementasikan dengan baik oleh para pelaksana kebijakan.

Menurut Sahartier (dalam Wahab, 2004 : 51) Implementasi dapat dikatakan sebagai suatu untuk memahami apa yang nyatanya terjadi sesudah suatu program dinyatakan berlaku atau dirumuskan, yakni kejadiankejadian dari kegiatan yang timbul sesudah disahkannya pedoman-pedoman kebijakan Negara, yang mencakup baik usaha-usaha untuk mengadministrasikannya maupun untuk menimbulkan dampak nyata pada masyarakat.

Dengan demikian kebijakan dipandang sebagai suatu proses, yang meliputi formulasi, implementasi, dan evaluasi, suatu kebijakan di formulasikan atau dirumuskan dengan maksud untuk mencapai tujuan tertentu. Dari beberapa pengertian tersebut maka dapat disimpulkan bahwa implementasi kebijakan adalah serangkaian tindakan yang ditetapkan atau dilaksanakan dan dilakukan oleh pemerintah yang mempunyai tujuan tertentu demi kepentingan masyarakat. Keselamatan Kesehatan Kerja pada setiap perusahaan sudah di dasari landasan 
hukum, maka setiap kegiatan yang dilakukan oleh pekerja sudah termasuk dalam landasan hukum. Dan landasan hukum yang digunakan dalam setiap perusahaan ialah Undang-undang 1970 nomor 1 tentang tenaga kerja berhak mendapat perlindungan atas keselamatan dalam melakukan pekerjaan. Dan masuk juga dalam Peraturan Menteri Tenaga Kerja RI nomor PER 05/MEN/1996 tentang Sistem Manajemen Keselamatan dan Kesehatan Kerja secara keseluruhan yang meliputi struktur organisasi, perencanaan, tanggung eJournal Ilmu Pemerintahan, Volume 2, Nomor 1, 2014: $1-11$

Pelaksanaan, prosedur, proses, dan sumber daya yang dibutuhkan bagi pengembangan, penerapan, pencapaian, pengkajian, dan pemeliharaan kebijakan keselamatan dan kesehatan kerja dalam rangka pengendalian resiko. Suma'mur (2001:1) Kesehatan kerja adalah spesialisasi dalam ilmu kesehatan atau kedokteran beserta prakteknya yang bertujuan agar para pekerja atau masyarakat pekerja memperoleh derajat kesehatan setinggi-tingginya, baik fisik, mental maupun sosial, dengan usaha preventif, terhadap penyakit atau gangguangangguan kesehatan yang diakibatkan faktor-faktor pekerjaan dan lingkungan kerja serta terhadap penyakitpenyakit umum. Tujuan kesehatan kerja adalah untuk melindungi pekerja dari segala hal yang dapat merugikan kesehatan akibat kerja.

Lingkungan adalah lingkungan tempat kerja yang terjadi akibat dari suatu kegiatan di pelabuhan : temperatur atau suhu atau dingin, kelembaban, berdebu, kebisingan, dan lain-lain. Faktor-faktor di atas dapat berdiri sendiri atau bahkan saling interaksi atau bersama-sama terlibat mempengaruhi terjadinya kecelakaan. Dalam melakukan pemeriksaan kecelakaan, faktor-faktor tersebut harus menjadi dasar pemikiran untuk mencari penyebab kecelakaan serta membuat koreksi dan tindakan pencegahan. Lingkungan tempat kerja merupakan suatu faktor yang dapat menimbulkan gangguan kesehatan, karena hal tersebut menimbulkan sakit akibat bila terlalu lama.

\section{Aspek Legal K3 RS}

Rumah sakit merupakan tempat kerja dimana terdapat karyawan, orang sakit, pengunjung, alat medis dan non medis. Rumah sakit dibangun dilengkapi dengan peralatan yang dijalankan dan dipelihara untuk sedemikian rupa untuk menjaga dan mencegah kebakaran serta persiapan dalam menghadapai bencana maupun kebakaran.

\section{Rumah sakit :}

- Padat modal

- Padat teknologi 
- Padat Karya

- Padat Sistem

Kesehatan dan Keselamatan Kerja adalah kesehatan dan keselamatan yang berkaitan dengan tenaga kerja, pekerjaan dan lingkungan kerja, yang meliputi segala upaya untuk mencegah dan menanggulangi segala sakit dan kecelakaan akibat kerja.

\section{Dasar Hukum dan Pedoman :}

- UU No.1 $/ 1970$ tentang keselamatan kerja

- UU No.23 /1992 tentang kesehatan

- Permenkes RI No. 986/92 tentang kesehatan lingkungan RS

- Permenkes RI No. 472 tahun 1996 tentang pengamanan bahan berbahaya bagi kesehatan

- SK Menkes No.351 tahun 2003 tentang Komite K3 sektor Kesehatan

- Permenaker no.05/Men/1996 tentang Sistem Manajemen Keselamatan dan Kesehatan Kerja

- Keputusan Dir.Jen. P2PLP nomor 1204 tahun 2004 tentang persyaratan kesehatan lingkungan rumah sakit

- Pedoman K3 di rumah sakit th 2006 ( BinKesja DepKes )

- Pedoman teknis pengelolaan limbah klinis dan desinfeksi dan sterilisasi di rumah sakit tahun 2002.

\section{Sistem Manajemen K3-RS}

Merupakan bagian dari sistem manajemen RS secara keseluruhan yang meliputi struktur organisasi, perencanaan, tanggung jawab, pelaksanaan, prosedur, proses, dan sumber daya yang dibutuhkan bagi pengembangan, penerapan, pencapaian, dan pemeliharaan kebijakan kesehatan dan keselamatan kerja dalam rangka pengendalian resiko yang berkaitan dengan kegiatan kerja guna terciptanya tempat kerja yang sehat, aman, efisien, dan produktif.

\section{Tujuan SM-K3RS}

Menciptakan suatu sistem kesehatan dan keselamatan kerja di rumah sakit dengan melibatkan unsur manajemen, karyawan, kondisi dan lingkungan kerja yang terintegrasi dalam rangka mencegah dan mengurangi kecelakaan dan penyakit akibat kerja.

\section{Tahap Penerapan K3-RS}

- Tahap persiapan

- Tahap pelaksanaan

- Tahap pemantauan dan evaluasi

\section{Tahap Persiapan}

- Komitmen manajemen : kebijakan, penyediaan dana, sarana dan prasarana untuk mendukung kegiatan K3 RS

- Membentuk Unit Organisasi K3 di RS yang terlihat dalam struktur organisasi RS

\section{Susunan / Organisasi K3-RS}


Susunan Unit K3-RS terdiri dari :

- Bidang I : Bidang pengamanan peralatan medik, pengamanan radiasi dan limbah radioaktif

- Bidang II : Bidang pengamanan peralatan nonmedik, pengamanan dan keselamatan bangunan

- Bidang III : Bidang pengembangan sanitasi sarana kesehatan

- Bidang IV : Bidang pelayanan kesehatan kerja dan pencegahan penyakit akibat kerja

- Bidang V : Bidang pencegahan dan penanggulangan bencana

Tugas Unit Organisasi K3-RS

- Memberi rekomendasi dan pertimbanagan kepada Direktur RS tentang masalah-masalah yang berkaitan dengan K3_RS

- Membuat program K3-RS

- Melaksanakan program K3_RS

- Melakukan evaluasi program K3RS

\section{Tahap Pelaksanaan}

Program K3-RS

1. Pelaksanaan kesehatan kerja bagi karyawanb ( prakerja, berkala, khusus )

2. Upaya pengamanan pasien, pengunjung dan petugas

3. Peningkatan kesehatan lingkungan

4. Sanitasi lingkungan RS

5. Pengelolaan dan pengolahan limbah padat, cair, gas
6. Pencegahan dan penanggulangan bencana (Disaster program)

7. Pengelolaan jasa, bahan dan barang berbahaya

8. Pendidikan dan pelatihan K3

9. Sertifikasi dan kalibrasi sarana, prasarana, dan peralatan RS

10. Pengumpulan, pengolahan dan pelaporan $\mathrm{K} 3$

\section{Tahap Pemantauan dan Evaluasi}

1. Inspeksi dan audit program $\mathrm{K} 3$

2. Perbaikan dan pengendalian $\mathrm{K} 3$ yang didasarkan atas hasil temuan dari audit dan inspeksi

3. Rekomendasi dan tindak lanjut hasil evaluasi program K3

\section{Indikator keberhasilan SM-K3RS}

1. Terlaksanakannya program K3-RS

2. Penurunan angka kecelakaan dan penyakit akibat kerja

\section{Ruang lingkup K3 di Rumah Sakit}

- Sarana higene yang memantau pengaruh lingkungan kerja terhadap tenaga kerja antara lain pencahayaan, bising, suhu / iklim kerja.

- Sarana Keselamatan kerja yang meliputi pengamanan pada peralatan kerja, pemakaian alat pelindung diri dan tanda/ramburambu peringatan dan alat pemadam kebakaran.

- Sarana Kesehatan Kerja yang meliputi pemeriksaan awal, berkala 
dan khusus, gizi kerja, kebersihan diri dan lingkungan.

- Ergonomi yaitu kesehatan antara alat kerja dengan tenaga kerja

\section{Sumber Stres Di Rumah Sakit}

- Beban kerja terlalu berat

- Konflik dan ketidakjelasan peran

- Kurang supervisi dan pengarahan

- Bekerja di daerah yang asing

- Suara gaduh

- Kurang berperan -> kepuasan kerja rendah

- Kurang penghargaan

- Kerja bergilir

- Pajanan terhadapa toksikan,pasien infeksius

- Ketidakpastian (politik, kerja kontrak)

\section{Keadaan Darurat di RS}

Keadaan darurat adalah setiap kejadian yang dapat menimbulkan gangguan terhadap kelancaran operasi/kegiatan di lingkungan RS

Jenisnya :

- Kebakaran

- Kecelakaan, contoh : terpeleset dan tertusuk benda tajam

- Gangguan tenaga, contoh : gangguan listrik, air, dll

- Ganggua keamanan, contoh : huruhara, demonstrasi, pencurian

- Bencana alam, contoh : gempa bumi, angin topan, banjir, dll
- Keadaan darurat di ruangan, ruang bedah, ICCU $<$ contoh : gagal jantung, gagal napas

\section{Pemantauan Lingkungan Kerja}

Laporan pemantauan lingkungan kerja dilakukan

- Penyehatan lingkungan rumah sakit dilakukan setiap triwulan secara berjenjang

- Pemantauan kualitas udara ruang minimal 2 kali dalam setahun

- Pemantauan bahan makanan dilakukan minimal 1 kali setiap bulan diambil sampel untuk konfirmasi laboraturium

- Tenaga kerja dipewriksa kesehatannya 1 kali setahun

- Pemeriksaan air minum dan air bersih dilakukan 2 kali setahun

- Perbaikan tangga ( dilengkapi karet anti terpelesetr), ram, pintu dan tangga darurat

- Penyempurnaan pengolahan limbah

- Pemasangan detektor asap

- Pemasangan alat komunikasi

- Perbaikan dan penyempurnaan vertilasi dan pencahayaan

\section{Untuk Karyawan}

- Inventarisasi seluruh karyawan beserta tempat kerja

- Laporan karyawan yang sakit kronis 
- Jumlah kunjungan karyawan yang berobat di Poli

- Usulan medikal check-up untuk karyawan yang sering sakit (absensi)

- Usulan skrening test untuk pegawai yang bekerja di tempat resiko tinggi ( IGD, dapur, laundr, lab )

- Usulan vaksinasi pegawai terutama yang bekerja di tempat resiko tinggi

- Usulan pelatihan K3 diluar dan didalam Rumah Sakit

- Usulan pembelian APD ( topi, masker, pakaian kerja, sepatu, sarung tangan)

- Perbaikan kesejahteraan karyawan (makanan tambahan, vasilitas kesehatan)

\section{Manajemen Resiko di RS}

- Rekognisi hazards

- Menilai risiko hazards

- Intervensi mengendalikan resiko

\section{Tujuan Manajemen Resiko}

- Meminimasikan kerugian

- Meningkatkan kesempatan/peluang

- Memotong mata rantai kejadian kerugian

- Pencegahan terhadap terjadinya kerugian akibat kecelakaan dan atau penyakit akibat kerja.

\section{Hazard VS Risk}

- Hazard is asource or situation with a potential for harm in terms of human injury or ill health, damage to property or the environment, or a combination of these.

- Hazard is the potential for the risk factor to be realized in particular situation

- Risk is the probability for hazard to be realized

\section{Hazard di RS}

1. Hazard Kecelakaan

- Physical extention -> Hernia, back injury

- Kebakaran dan bencana alam

- Gas dalam tabung

- Larutan, uap dan gas mudah terbakar dan meledak

- Alat elektronik

2. Hazard penyakit infeksi

3. Hazard penyakit noninfeksi

- Kimia (desinfektan, etilenoksida, antikanker, gas anestesi)

- Fisik ( panas, bising, radiasi)

- Mutagen dan terarogen

- Dermatologik

- Stres

\section{Hirarki Manajemen Risiko}

- Eliminasi

- Subtitusi

- Redukasi cara teknis ( isolasi, ventilasi, dll )

- Reduksi cara administratif ( SOP, edukasi, dll )

- Alat pwelindung diri 
Dalam Undang-Undang Nomor 23 Tahun 2003 tentang Kesehatan, Pasal 23 dinyatakan bahwa upaya Kesehatan dan Keselamatan Kerja (K3) harus diselenggarakan di semua tempat kerja, khususnya tempat kerja yang mempunyai risiko bahaya kesehatan, mudah terjangkit penyakit atau mempunyai karyawan paling sedikit 10 orang. Jika memperhatikan isi dari pasal di atas maka jelaslah bahwa Rumah Sakit (RS) termasuk ke dalam kriteria tempat kerja dengan berbagai ancaman bahaya yang dapat menimbulkan dampak kesehatan, tidak hanya terhadap para pelaku langsung yang bekerja di RS, tapi juga terhadap pasien maupun pengunjung RS. Sehingga sudah seharusnya pihak pengelola RS menerapkan upaya-upaya K3 di RS.

\section{PENUTUP}

Kesehatan dan Keselamatan Kerja (K3) adalah salah satu bentuk upaya untuk menciptakan tempat kerja yang aman, sehat, bebas dari pencemaran lingkungan, sehingga dapat mengurangi dan atau bebas dari kecelakaan kerja dan penyakit akibat kerja yang pada akhirnya dapat meningkatkan efisiensi dan produktivitas kerja

Bahaya yang dihadapi dalam rumah sakit ; Bahaya kebakaran dan ledakan dari zat/bahan yang mudah terbakar atau meledak (obat- obatan), Bahan beracun, korosif dan kaustik, Bahaya radiasi, Luka bakar ,Syok akibat aliran listrik, Luka sayat akibat alat gelas yang pecah dan benda tajam \& Bahaya infeksi dari kuman, virus atau parasit.

\section{DAFTAR PUSTAKA}

Anita, D. (2012). DASAR

KESELAMATANDAN

KESEHATAN KERJA. Jember : UPT Penerbit UNEJ

Ivana, A.(2014). Analisa Komitmen

Manajemen Rumah Sakit (RS)

Terhadap Keselamatan Dan

Kesehatan Kerja (K3) Pada RS

Prima Medika Pemalang.

Semarang : JURNAL

KESEHATAN

MASYARAKAT

Mulyono, M. Hadi dkk. (2012). Faktor

Yang Berpengaruh Terhadap

Kinerja Perawat di RS Tingkat

III. 16. 06. 01. Jurnal AKK. Vol 2

No. 1.

Nurmalia, Devi. (2012). Pengaruh

Program Mentoring Keperawatan terhadap Penerapan Budaya

Keselamatan Pasien di Ruang Rawat Inap Rs. Sultan Angung Semarang. Tesis. FKM UI

Permadhi, A. (2013). Hubungan Budaya

Keselamatan Pasien Dalam

Pelayanan Keperawatan dan 
Insiden Keselamatan Pasien di

Instalasi Rawat Inap RSD dr.

Soebandi. Skripsi. Jember.

.Rejeki Sri .(2016).Kesehatan dan

Keselamatan Kerja. Kementrian

Kesehatan Republik Indonesia

Reno Afriza Neri, Y. L. (2018).

\section{ANALISIS PELAKSANAAN \\ SASARAN KESELAMATAN.}

Artikel Penelitian Jurnal Kesehatan

Andalas , 51-52

Simamora, R. H. (2011).

$\begin{array}{lrr}\text { ROLECONFLICT } & \text { OF } & \text { NURSE } \\ \text { RELATIONSHIP } & & \text { WITH } \\ \text { PERFORMANCE } & \text { IN } & \text { THE } \\ \text { EMERGENCY } & \text { UNIT } & \text { OF } \\ \text { HOSPITALS } & \text { RSD } & \text { DR. } \\ \text { SOEBANDI JEMBER. } & \text { The } \\ \text { Malaysian Journal of } & \text { Nursing, } \\ \text { 3(2), 23-32. } & & \end{array}$

Salmawati, L (2015). HUBUNGAN

PENERAPAN

SISTEM

MANAJEMEN KESELAMATAN

DAN KESEHATAN KERJA

DENGAN MOTIVASI KERJA

DAN STRES KERJA PADA

PERAWAT DI RUMAH SAKIT

UMUM ANUTAPURA PALU.

Palu : JURNAL MANAJEMEN

PELAYANAN KESEHATAN.

Yuliandi, C.D.(2019) PENERAPAN

KESELAMATAN

DAN

KESEHATAN KERJA (K3) DI
LINGKUNGAN KERJA ALAI

INSEMINASI BUATAN (BIB)

LEMBANG. Lembang :

Manajerial. 